\title{
Pancasila sebagai Dasar dan Ideologi Bangsa (Pentingnya Rumusan Butir-butir Pancasila sebagai Dasar Pendidikan Moral dan Pemersatu Keberagaman Bangsa Indonesia)
}

\author{
Nia Yunia Sari, M.Pd.I \\ Institut Agama Islam Riyadlotul Mujahidin Ngabar Ponorogo \\ Sarivunia01@gmail.com
}

\section{Abstrak}

Eksistensi suatu bangsa dapat dilihat dari sejauh mana bangsa tersebut mampu menunjukkan kemajuan peradaban. Berkembangnya suatu bangsa adalah peradaban yang juga berkembang sebagai produk yang di dalamnya terdapat masyarakat berbudaya, bermoral dan memiliki pola fikir yang baik. Setiap bangsa memiliki keberagaman budaya, adat istiadat, bahasa, kepercayaan dan lain-lain. Akan tetapi, setiap bangsa juga memiliki dasar yang menjadi pedoman dalam pelaksanaan nilai-nilai kehidupan bermasyarakat, berbangsa dan bernegara. Suatu bangsa dapat dikatakan kuat apabila dasar dan pedoman yang dimiliki teraplikasi dengan baik untuk merangkul keberagaman dan perbedaan yang ada sehingga setiap keberagaman dan perbedaan menjadi indah dalam perkembangan bangsa. Salah satu dasar dan ideologi bangsa Indonesi adalah pancasila. Sebagai ideologi bangsa, pancasila menjadi pandangan dan pegangan hidup masyarakat. Butirbutir yang terkandung dalam pancasila memiliki nilai-nilai aturan bermasyarakat, berbangsa, bernegara, berketuhanan, keberagaman, dan nilai norma, meskipun dewasa ini bangsa Indonesia dihadapkan pada permasalahan yang memanas.

Kata Kunci: Pancasila, ideologi, moral, keberagaman 


\section{A. Pendahuluan}

Setiap bangsa yang ingin berdiri kokoh dan mengetahui dengan jelas kearah mana tujuan yang ingin dicapainya sangatlah meemrlukan pandangan hidup. Dengan pandangan hidup inilah suatu bangsa akan memandang persoalan-persoalan yang dihadapinya dan menetuikan atrah serta cara bagaimana bangsa itu mampu memecahkan setiap persoalan yang ada. Tanpa memiliki pandangan hidup suatu bangsa tidak akanmemiliki dasar,pedoman, pegangan dan akan terombang ambing dlam menghadapi setisp persoalan didalam masyarakat sendiri maupun persoalan besar umat manusia. Begitupun halnya dengan bangsa Indonesia. Indonesia memiliki beberapa dasar ideologi sebagai pedoman dalam konsistensi reformasi bangsa, yakni Undang-Undang Dasar Negara Republik Indonesia, Pancasila dan ketetapan MPR. Ketiga dasar pedoman hidup tersebut menjadi tonggak, pedoman, pegangan dalam membangun bangsa serta untuk memecahkan setiap persoalan-persoalan yang ada.

Dewasa ini, pertumbuhan dan perkembangan bangsa Indonesia mengalami suatu perubahan yang sangat pesat dari segala aspek kehidupan. Modernisasi dunia mampu diikuti dengan baik oleh masyarakat Indonesia. Masyarakat Indonesia semakin maju. Namun, dalam setiap inci perkembangannya, juga muncul persoalan-persoalan yang jika terus menerus berkelanjutan tanpa adanya solusi, maka ini akan membuat sebuah perubahan yang mengarah pada kerapuhan dan kehancuran. Berbagai masalah kian menjamur. Hampir setiap sektor kehidupan tidak luput dari permasalahan yang tidak kunjung selesai. Sebagai contoh berita online dan offline yang hampir setiap saat menayangkan tawuran pelajar, demonstrasi UU terbaru oleh mahasiswa dan masyarakat bahkan anak-anak kecil di 
bawah umur ikut andil di dalamnya. Pelecehan seksual, nyawa dan kehidupan seseorang hanya seperti mainan yang setiap saat dapat diambil begitu mudah. Remaja dan minuman keras serta narkoba di setiap penjuru kota. Perampokan, perkosaan, bunuh diri, faktor ekonomi atau penghianatan pasangan dan masih banyak lagi.

Dalam permasalahan ini pancasila seakan hanya menjadi sebuah pajangan, hanya sebagai sebuah tulisan yang tidak memiliki nilai. Peringatan hari kesaktian pancasila setiap tanggal 1 Oktober dan peringatan hari sumpah pemuda setiap tanggal 28 Oktober hanya menjadi sebuah ingatan dan peringatan tanpa diketahui kembali makna di balik peringatan tersebut. Lagu pancasila dan lagu kebangsaan Indonesia hanyalah menjadi sebuah lagu yang bahkan anak-anak kekinian banyak yang tidak hafal liriknya apalagi maknanya. Perilaku-perilaku penyimpangan seakan telah menjamur rata dalam jiwa-jiwa masyarakat indonesia. Makna pancasila seakan hilang dari peredaran dan ini salah! karena pancasila adalah pedoman dasar dalam pembentukan moral, perkembangan berfikir, pegangan dalam setiap perbedaan dan keberagaman yang dimiliki bangsa Indonesia.

Kondisi ini harus segera dicari solusi yang tepat, modernisasi dunia harus bangsa ini ikuti akan tetapi jangan sampai meninggalkan nilai-nilai luhur yang dimiliki. Penyimpangan perilaku dan moral harus segera dihentikan. Oleh karenanya diperlukan upaya serius untuk mengembalikan etika, moral, mental agar bisa kembali pada nilai-nilai luhur, pada budaya bangsa Indonesia. Butuh perjuangan yang keras untuk mewujudkannya. Makna dari setiap butir Pancasila harus kembali difahami dan diaplikasikan dalam kehidupan masyarakat Indonesia sebagai usaha untuk mewujudkan cita-cita reformasi dan pelaksanaan nilai kehidupan bermasyarakat, berbangsa dan 
bernegara secara konsekuen serta untuk mengakhiri berbagai persoalan yang terjadi saat ini, jelas memerlukan kesadaran dan komitmen masyarakat untuk memantapkan persatuan dan kesatuan nasional yang hanya dapat dicapai apabila setiap warga mampu hidup dalam kemajemukan dan mengelolanya dengan baik. Pancasila merupakan salah satu dasar dan sebuah ideologi untuk membangun bangsa yang majemuk. Oleh karena itulah pemahaman yang komperehensif terhadap pancasila merupakan suatu keharusan dan kebutuhan masyarakat.

\section{B. Kedudukan Pancasila bagi Bangsa Indonesia}

Dalam kehidupan bangsa Indonesia pancasila memiliki kedudukan yang sangat penting. Seperti yang ditunjukkan dalam ketetapan MPR NO II/MPR/1978, pancasila adalah jiwa seluruh rakyat Indonesia, kepribadian bangsa Indonesia, pandangan hidup dan dasar Negara bagi rakyat Indonesia. Oleh karena itu, pancasila sekaligus menjadi tujuan hidup bangsa Indonesia, pancasila merupakan pandangan hidup, kesadaran dan cita-cita moral yang meliputi kejiwaan dan watak yang sudah berurat akar di dalam kebudayaan bangsa Indonesia.

Seperti diketahui oleh masyarakat Indonesia bahwa pancasila adalah jiwa bangsa yang memberi kekuatan hidup bagi bangsa Indonesia. ${ }^{1}$ Untuk itu kelestarian keampuhan dan kesaktian pancasila harus dipertahankan dan diusahakan secara nyata dan terus menerus penghayatan dan pengamalan nilai-nilai luhur yang terkandung di dalamnya oleh setiap warga negara Indonesia. Setiap penyelenggaraan negara serta setiap lembaga kenegaraan dan lembaga kemasyarakatan baik pusat maupun daerah.

Kansil dan Christin, Modul Pancasila Dan Kewarganegaraan (Jakarta: PT Pradnya Paramita, 2005) hal. 21 
Terdapat empat kedudukan penting pancasila, yaitu: sebagai dasar dan ideologi bangsa, sebagai pandangan hidup, sebagai pemersatu bangsa dan sebagai filosofische Grondslag.

1. Pacasila sebagai dasar dan ideologi bangsa: Sebagai dasar Negara: Pancasila berarti menjadi dasar untuk mengatur penyelenggaraan Negara dan seluruh warga Negara Indonesia. Dalam Pembukaan Undang-Undang Dasar Negara Republik Indonesia Tahun 1945 alinea keempat terdapat rumusan sila-sila pancasila sebagai dasar Negara Indonesia. Rumusan sila-sila pancasila itulah dalam hukum positif Indonesia secara yuridis-konstitusional sah, berlaku, dan mengikat seluruh lembaga Negara, lembaga masyarakat, dan setiap warga negara tanpa terkecuali. Sebagai ideologi Negara: dimaknai sebagai sistem kehidupan nasional yang meliputi aspek etika/moral, politik, ekonimi, sosial budaya, dan pertahanan keamanan dalam rangka pencapaian cita-cita dan tujuan bangsa yang berlandaskan dasar Negara. ${ }^{2}$

2. Pancasila adalah suatu pandangan hidup bagi bangsa Indonesia yang lahir melalui proses yang sangat panjang, dilahirkan dengan pemikiran-pemikiran yang sangat panjang dan luar biasa, dan dimatangkan dengan sejarah perjuangan bangsa Indonesia dengan melihat banyak faktor. Pemersatu bangsa, memberi petunjuk dalam mencapai kesejahteraan dan kebahagiaan lahir batin dalam masyarakat Indonesia yang beraneka ragam sifatnya. Jika berbicara tentang PANCASILA sebagai pandangan hidup, maka yang dimaksudkan adalah pancasila yang dirumuskan dalam Pembukaan UUD 1945.

${ }^{2}$ Sumber: Buku Empat Pilar Kehidupan Berbangsa Dan Bernegara, 2012, hal. 87 
3. Pancasil sebagai pemersatu bangsa adalah bahwa pancasila merupakan pegangan bersama bagi seluruh rakyat Indonesia. Dikehendaki dan tertanam dalam kalbu rakyat Indonesia yang mempersatukan seluruh rakyat Indonesia.

4. Pancasila sebagai filosofische Gronslag yaitu sebagai pondamen, filsafat, pikiran yang mendalam. Fondamen: Hakikat, komitment, pondasi, asas, dasar/landasan pokok. Filsafat: Usaha pemikiran mendalam, hasil renungan manusia yang mendominasikan akal dan kalbu untuk memperoleh suatu pandangan. Kebenaran dalam Filsafat Pancasila (a) Kebenaran yang dibatasi waktu dan tempat. (b) Hakiki (Kebenaran dalam Agama/Kebenaran mutlak dari Tuhan Yang Maha Esa. ${ }^{3}$

\section{Pancasila sebagai Dasar dan Ideologi Bangsa}

Pancasila sebagai dasar dan ideologi bangsa merupakan hasil kesepakatan para founding fathers yang kemudia familiar disebut sebagai "perjanjian luhur" bangsa indonesia. ${ }^{4}$ Pancasila lahir dari kebudayaan bangsa Indonesia dan bukan dari negara lain. Sehingga pada hakikatnya pancasila merupakan manifestasi bangsa Indonesia yang telah tumbuh dalam jiwa masyarakat Indonesia dan kemudian diaplikasikan dalam kehidupan berbangsa dan bernegara.

Pancasila berarti rangkaian lima aturan tentang dasardasar atau prinsip-prinsip petunjuk prilaku dan perbuatan masyarakat Indonesia. Kelima sila tersebut kemudian

3 Bahan tayang materi sosialisasi empat pilar mpr ri. Jakarta: sekretariat jendral MPR RI, 2016) hal. 6-7

${ }^{4}$ Jazim Hamidi dan Mustafa Luthfi, Civic Education Antara Realitas Politik Dan Implementasi Hukumnya (Jakarta: Pt Gramedia Pustaka Utama, 2010) hal. 52 
berperan menjadi pandangan hidup, keyakinan, pegangan, pedoman atau cita-cita bangsa yang berfungsi sebagai dasar dan ideologi dalam mengambil suatu keputusan terhadap berbagai macam persoalan yang dihadapi bangsa indonesia.

Pancasila sebagai dasar dan ideologi bangsa merupakan suatu konsep yang dijadikan sebagai pegangan untuk mencapai suatu tujuan bangsa dalam kehidupan berbangsa dan bernegara. Pancasila sebagai suatu ketetapan bagi seluruh warga negara Indonesia, seperti yang telah kita tahu bahwa warga Indonesia memiliki keanekaragamaan yang kompleks, baik dalam bidang budaya, ras, warna kulit, dll. Oleh karena itu untuk mencapai tujuan bangsa kita, Indonesia harus bersatu membentuk kekuatan sehingga dapat rukun, damai, kuat, dan dinamis. Maka dijadikanlah pancasila sebagai suatu pegangan yang mengatur pola pikir warga negara agar bisa mencapai tujuan bangsa.

Tujuan Bangsa kita adalah tujuan yang telah tertera dalam Pembukaan UUD 1945, yang diantaranya melindungi segenap warga negara indonesia dan seluruh tumpah darah Indonesia, memajukan kesejahteraan umum, mencerdaskan kehidupan bangsa, dan ikut melaksanakan ketertiban dunia berdasarkan kemerdekaan abadi dan keadilan sosial. Untuk mencapai tujuan tersebut, tentunya banyak hal yang harus dilakukan, salah satunya adalah menjadikan Pancasila Sebagai Ideologi Bangsa, Pancasila menjadi dasar dalam kehidupan berbangsa dan bernegara.

Pancasila haruslah bersifat universal mencakup segala macam nilai-nilai sosial dan budaya Indonesia serta menjadi orientasi dalam hidup oleh seluruh masyarakatnya. Sebagai ideologi bangsa, maka keberadaannya selalu diimplementasikan ke dalam perilaku kehidupan dalam

5 Tobroni dkk. Pendidikan Kewarganegaraan, Demokrasi, HAM, Civic Society dan Multikulturalisme (Malang: Posapom, 2007), hal. 8 
rangka berbangsa, bernegara dan bermasyarakat. Kalau dikaji dari butir-butir kelima sila dalam ideologi Pancasila tersebut, sebenarnya sudah mencakup gambaran pembentukan karakter manusia Indonesia yang ideal, sebagai mana yang diharapkan para penggali dari pancasila itu sendiri.

Pancasila dalam perannya sebagai ideologi negara memiliki beberapa dimensi. Dimensi-dimensi yang dimiliki oleh Pancasila, yakni: Dimensi Realita (cerminan kehidupan berbangsa), Dimensi idealisme (harapan untuk mencapai masa depan yang lebih baik), dan Dimensi flexibilitas (kemampuan Pancasila dalam memengaruhi meyesuaikan diri dengan perkembangan masyarakat). Dimensi-dimensi ini bisa dirasakan dalam kehidupan kita sehari-hari.

Sejarah telah mengungkapkan bahwa pancasila adalah jiwa masyarakat Indonesia. Yang memberi kekuatan hidup kepada bangsa serta membimbingnya dalam mengejar kehidupan lahir yang makin baik dalam masyarakat Indonesia yang adil dan makmur. Menyadarai bahwa untuk kelestarian keampuhan dan kesaktian pancasial itu perlu diusahakan secara nyata dan terus menerus penghayatan dan pengamalan nilai-nilai luhur yang terkandung di dalamnya oleh setiap warga negara Indonesia, setiap penyelenggaraan negara serta setiap lembaga kenegaraan dan lembaga kemasyarakatan baik pusat maupun daerah. ${ }^{6}$

Sebagai dasar negara dan ideologi bangsa, pancasila memiliki fungsi yang sangat penting, yaitu:

1. Pancasila Sebagai Ideologi Persatuan: Fungsi Pancasila sebagai pedoman agar bangsa Indonesia tetap bersatu dan tidak terpecah belah sangatlah penting. Seperti yang telah saya katakan diatas bahwa Indonesia memiliki

${ }^{6}$ Kansil dan Christin ST Kansil, Modul Pancasila Dan Kewarganegaraan (Jakatra: PT Pradnya Paramita, 2005), hal. 21. 
Keanekaragam suku yang sangat banyak sehingga apabila terpecah belah akan sangat beresiko dan memberikan banyak dampak negatif. Pancasila Menjadi Ideologi persatuan dengan membangun suatu konsep atau ide yang menjadi watak warga negaranya, sehingga memiliki kepribadian dan rasa percaya diri yang tinggi. Pancasila sebagai Ideologi Persatuan dapat di analogikan seperti "pancasila membangun karakter bangsa (character Building oleh pancasila).

2. Pancasila Sebagai Ideologi Terbuka: Pancasila Sebagai Ideologi terbuka artinya pancasila dapat dikembangkan nilai-nilainya agar menjadi suatu ideologi yang lebih baik seiring terjadinya kemajuan dalam kehidupan. "Terbuka" yang dimaksud di sini bukanlah mengubah pancasila, namun mengarahkan penerapan nilai-nilai pancasila menjadi lebih mapan dan sesuai dengan perkembangan zaman.

\section{Keberagaman Bangsa Indonesia dan Pentingnya Pendidikan Moral}

Indonesia adalah salah satu negara multikultur terbesar di dunia. Hal ini dapat terlihat dari kondisi sosiokultural maupun geografis Indonesia yang begitu kompleks, beragam dan luas. Indonesia terdiri atas sejumlah besar kelompok etnis, budaya, agama dan lain-lain yang masing-masing plural (jamak) dan sekaligus juga heterogen "aneka ragam". Sebagai negara yang plural dan heterogen, Indonesia memiliki kekayaan multi etnis, multi kultur, dan multi agama yang semuanya merupakan potensi untuk membangun negara.

${ }^{7}$ Kusumohamidjojo, B. Kebhinekaan Masyarakat Indonesia: Suatu Problematik Filsafat Kebudayaan. (Jakarta: Grasindo. 2000), hal. 45. 
Bhineka tunggal ika adalah motto atau semboyan yang dimiliki oleh bangsa Indonesia. Moto ini sangatlah penting bangi rakyat Indosesia, bahkan motto ini tertulis rapih pada lambang negara Indonesia. Frasa ini berasal dari jawa kuno yang memiliki arti menggambarkan keadaan bangsa Indonesia yaitu "berbeda-beda tetapi tetap satu jua". Diterjemahkan perkata, kata "Bhineka" memiliki makna "beraneka ragam". Dari motto tersebut nampak jelas bahwasanya Indonesia memiliki banyak sekali keberagaman dari berbagai aspek.

Masyarakat Indonesia diwarnai oleh berbagai macam perbedaan sebagai akibat dari kondisi wilayah, suku bangsa, budaya, agama, adat istiadat, bahasa dan lain-lain. Perbedaan yang terdapat pada masyarakat merupakan keberagaman Indonesia yang dapat dirangkai dalam bingkai Bhineka Tunggal Ika. Makna Bhineka Tunggal Ika memiliki makna meskipun berbeda-beda tetapi pada kahikatnya bangsa Indonesia tetap satu kesatuan. Semboyan ini menggambarkan persatuan dan kesatuan bangsa indonesia yang memiliki keberagaman suku bangsa, budaya, bahasa daerah, agama, kepercayaan, ras, adat istiadat, kebiasaan, maupun antar golongan.

Keberagaman adalah suatu kondisi dalam masyarakat yang terdapat banyak perbedaan dalam berbagai bidang. Perbedaan tersebut meliputi, suku, rasa, bahasa daerah, agama, kepercayaan, budaya dan masih banyak lainnya. Keberagaman bangsa Indonesia dipengaruhi oleh berbagai faktor, yaitu: letak strategis, kondisi negara kepulauan, perbedaan kondisi alam, keadaan transportasi dan komunikasi, penerimaan masyarakat terhadap perubahan. Keberagaman bangsa Indonesia memiliki dampak positif dan juga dampak negatif. Dampak positif adalah bahwa keberagaman memberikan banyak manfaat bagi 
perkembangan dan kemajuan. Sedangkan dampak negatifnya adalah, mengakibatkan ketidak harmonisan bahkan perpecahan bangsa dan negara.

Indonesia merupakan negara kepulauan yang penuh dengan keragaman budaya, suku bangsa, ras, etnis, agama maupun bahasa daerah. Meskipun kaya akan keberagaman, namu mereka tetaplah satu Indonesia. Keberagaman bangsa yang dimiliki menjadi aset berharga dan kekayaan bangsa. Keberagaman masyarakat multikultural sebagai kekayaan bangsa sekaligus di sisi lain sangat rawan memicu konflik dan perpecahan. Hal ini menggambarkan bahwasanya pada dasarnya tidaklah mudah mempersatukan suatu keberagaman tanpa didukung adanya kesadaran masyarakat, terlebih kondisi masyarakat Indonesia adalah masyarakat paling majemuk di dunia selain Amerika dan India.

Keberagaman budaya Indonesia dilengkapi oleh keragaman lain yang ada pada tatanan hidup masyarakat, baik perbedaan ras, suku, adat, budaya, bahasa, agama, dan golongan politik yang terhimpun dalam suatu ideologi bersama yakni Pancasila dan Bhineka Tunggal Ika. Persatuan dikembangkan atas dasar bhineka tunggal ika dengan memajukan pergaulan demi kesatuan dan persatuan bangsa. ${ }^{8}$ Sehingga Bhineka Tunggal Ika bukan hanya sebagai suatu slogan akan tetapi merupakan pemersatu bangsa.

Keberagaman bangsa Indonesia berlangsung berabadabad lamanya, sehingga Indonesia tumbuh dalam suatu keragaman yang komplek. Pada hakikatnya para Founding Father bangsa Indonesia telah menyadari akan keberagaman ini. Singkatnya bangsa Indonesia adalah bangsa multikultural dengan semangat Bhineka Tunggal Ika.

8 Kansil, C.S.T. dan S.T. Kansi, C. Modul Pancasila Dan Kewarganegaraan, (Jakarta: PT. Pradnya Paramita, 2006), hal. 25 
Berbeda-beda tetapi tetap satu jua. ${ }^{9}$ Ini dimaksudkan untuk mewudukan persatuan dalam keberagaman. Kunci yang sekaligus menjadi mediasi untuk mewujudkan cita-cita itu adalah toleransi.

Dalam keberagaman, moral menjadi sesuatu yang sangat penting dalam masyarakat. Norma dan toleransi merupakan perwujudan manusia yang bermoral. Dalam menjalani kehidupan bermasyarakat akan teratur, baik dan tertata dengan benar apabila terdapat suatu aturan yang sudah disepakati dalam masyarakat tersebut. Salah satu peraturan tersebut adalah tentang moral. Definisi umum moral dalam masyarakat adalah susila, yakni ajaran baik buruk dalam perbuatan, sikap, kewajiban, akhlak, budi pekerti, dan susila. Norma dan nilai-nilai merupakan unsurunsur yang terdapat dalam pendidikan moral dan dijadikan tolak ukur untuk menetapkan baik buruk suatu tindakan atau perbuatan.

Keberagaman yang dimiliki bangsa Indonesia memiliki peran strategis dalam penanaman nilai-nilai moral. Pendidikan moral sangatlah penting, mengingat begitu banyak perbedaan yang dimiliki. Salah satu nilai negatif yang dimiliki bangsa yang beragam adalah bahwa keberagaman akan sangat mudah menciptakan konflik dan perpecahan. Untuk itu betapa pentingnya moral dan pendidikan moral bagi masyarakat Indonesia.

Menurut Magnis-Suseno kata moral selalu mengacu pada baik buruknya manusia sebagai manusia. Sehingga bidang moral adalah bidang kehidupan manusia dilihat dari sisi kebaikannya manusia. Sikap moral disebut dengan moralitas, jadi moralitas adalah sikap dan perbuatan baik yang betul-betul tanpa pamrih. Hanya moralitaslah yang

${ }^{9}$ Mahfud C. Pendidikan Multikultural, (Yogyakarta: Pustaka Pelajar, 2005), hal. 10 
bernilai secara moral. ${ }^{10}$ Nilai moral merupakan nilai yang sangat penting bagi kehidupan manusia baik sebagai makhluk pribadi, makhluk Tuhan, maupun makhluk sosial. Nilai moral merupakan nilai yang dipakai sebagai dasar, tuntunan dan tujuan dalam kehidupan. Moral dapat pula diartikan sebagai ukuran baik buruk tingkah laku atau karakter. Sehingga dapat difahami bahwa istilah moral pada hakikatnya merujuk pada ukuran-ukuran yang diterima oleh suatu komunitas.

Nilai moral dalah suatu perbuatan yang di dalamnya mengandung makna yang berharga. Di dalam penanaman nilai moral maka harus diperhatikan dan ditanamkan tiga unsur penting yakni: (1) Pemahaman dan pengertian moral, yaitu kesadaran moral, rasional moral, atau alasan mengapa seseorang harus melakukan hal itu, suatu pengambilan keputusan berdasarkan nilai-nilai moral. (2) Perasaan moral, lebih pada kesadaran hal-hal yang baik dan tidak baik, perasaan mencintai kebaikan, sikap empati kepada orang lain merupakan ekspresi dari perasaan moral. (3) Tindakan moral, kemampuan untuk melakukan keputusan dan perasaan moral ke dalam prilaku-prilaku nyata. Tindakantindakan moral ini perlu difasilitasi agar muncul dan berkembang dalam pergaulan sehatri-hari.

Di Indonesia terdapat tiga jenis pendidikan yaitu: (a) Pendidikan Informal (b) Pendidikan Formal dan (c) Pendidikan Nonformal. Pendidikan informal merupakan pendidikan yang diperoleh dan dilaksanakan oleh keluarga dan lingkungan. Kedudukannya setara dengan pendidikan formal dan nonformal. Hal paling khas yang menjadi nilai

10 Asri Budiningsih, Pembelajaran Moral: Berpijak Pada Karakteristik Siswa Dan Budayanya (Jakarta: Rineka Cipta, 2004) h.24

11 Cheppy Haricahyono, Dimensi-Dimensi Pendidikan Moral (Semarang:IKIP Semarang Press, 1995) hal. 221 
lebih pendidikan ini dibanding dengan pendidikan lain adalah kemungkinan bedar akan tergali dan terkelolanya potensi setiap anak secara maksimal. Dalam lingkungan keluarga (informal) anak dilatih berbagai kebiasaan baik yang berhubungan dengan cekatan, kesopanan dan moral. Keyakinan yang bersifat eligius ditanamkan pada pendidikan ini. Kebiasaan baik dan keyakinan-keyakinan penting mendarah daging merupakan landasan yang sangat diperlukan untuk pembangunan.

Pendidikan informal merupakan jalur pendidikan keluarga dan lingkungan berbentuk kegiatan belajar secara mandiri yang dilakukan secara sadar dan bertanggung jawab. Pendidikan formal tidak hanya berwujud fisik yang terbatas ruang waktu saja tetapi merupakan sistem pendidikan tanpa bentuk dan tanpa akhir. Kapan saja, dimna saja pendidikan informal dapat dilaksanakan. ${ }^{12}$ Peran keluarga dalam pendidikan sangat mendukung terjadinya proses indentifikasi, internalisasi, panutan dan reproduksi langsung dari nilai-nilai moral yang hendak ditanamkan sebagai pola orientasi dari kehidupan keluarga. Lingkungan keluarga merupakan lahan paling subur untuk menumbuh kembangkan pendidikan moral.

Selanjutnya adalah pendidikan formal. Merupakan pendidikan yang dilakukan di sekolah dimana kegiatan belajar mengajarnya secara berjenjang dan berkesinambungan. Di Indonesia pendidikan formal merupakan pendidikan yang sangat menonjol karena sistem pendidikan sekolah yang semakin dan terus berkembang pesat.

Terakhir adal pendidikan nonformal. Adalah pendidikan luar sekolah yang secara potensial dapat

${ }^{12}$ Likumahua, Sastra Suatu Sarana Pendidikan Informal, (Salatiga: Widya Sari Press Salatiga, 2001), hal. 5 
membantu pendidikan formal dalam aspek-aspek tertentu. Yang dimaksudkan dengan pendidikan nonformal adalah pendidikan yang teratur, dengan sadar dilakukan tetapi tidak terlalu mengikat dan mengikuti peraturan-peraturan yang tetap. Jadi, pendidikan nonformal dapat disesuaikan waktu pelaksanaannya, materi yang diberikan, proses belajar mengajar serta falsilitas yang digunakan dengan kebutuhan masyarakat dapat dikatan bahwa pendidikan nonformal juga merupakan pendidikan yang resposif terhadap kebutuhan masyarakat. Pendidikan berlangsung seumur hidup dan dilaksanakan di dalam lingkungan keluarga, sekolah dan masyarakat. Oleh karena itu, Pendidikan moral merupakan tanggung jawab keluarga, sekolah dan masyarakat yang terangkum dalam tiga jenis pendidikan Indonesia itu.

\section{E. Rumusan Nilai Butir-Butir Pancasila sebagai Dasar Pendidikan Moral}

Pancasila sebagai pandangan hidup dan dasar negara membawa konsekuensi logis bahwa nilai-nilai pancasila harus dijadikan landasan pokok dalam berfikir dan berbuat dan hal ini mengharuskan bangsa Indonesia untuk merealisasikan niali-nilai pancasila ke dalam sikap dan prilaku nyata. Pendidikan karakter berbasis nilai-nilai luhur pancasila adalah media yang tepat untuk merelaisasikan hal tersebut. Tanpa adanya realisasio tersebut, maka pancasila hanya tinggal ucapan-ucapan tanpa makna.

Moral dalam kata lain disebut kesusilaan adalah keseluruhan norma yang mengatur tingkah laku manusia di masyarakat untuk melaksanakan perbuatan-perbuatan yang baik dan benar. Jadi pendidikan moral ditujukan untuk memagari manusia dari melakukan perbuatan yang buruk yang tidak sesuai dengan norma-norma yang ada. Dalam kurun satu dekade, Indonesia mengalami kemunduran moral 
dengan ditandai tingginya angka freesex dikalangan remaja, maraknya penggunaan narkoba, bentrokan antar warga dan remaja, maraknya kasus korupsi yang terungkap. Itu semua menunjukkan degradasi moral tidak hanya terjadi dikalangan masyarakat biasa.

Kebudayaan akan mempengaruhi cepat lambatnya pencapaian tahap-tahap perkembangan moral dan juga mempengaruhi batas tahap perkembangan yang dicapai. Dengan kata lain, bahwa individu yang memiliki latar belakang budaya daapat berkembang moralnya dengan individu lain yang berasal dari kebudayan lain atau perkembangan moral sangat dipengaruhi oleh faktor kebudayaan. ${ }^{13}$

Dalam pengaplikasian di dunia nyata, pancasila memuat nilai-nilai luhur yang sangat penting bagi masyarakat indonesia. Untuk menjaga konsistensi pengaktualisasian nilai pancasila kedalam praktik hidup berbangsa dan bernegara maka masyarakat harus memahami dengan baik makna yang terdapat dalam nilai-nilai pancasila, sehingga masyarakat akan mampu menjiwai semua tingkah laku atau moral kehidupan bernegara, berpolitik dan berpribadi.

Pancasila tidak hanya mengandung nilai budaya akan tetapi juga menjadi sumber hukum dasar nasional diberbagai bidang kehidupan. Nilai-nilai di dalamnya juga dijabarkan menjadi norma moral. Intisari nilai-nilai yang terkandung dalam pancasila yaitu: nilai (1) Sila Ketuhanan Yang Maha Esa: pada prinsipnya menegaskan bahwa bangsa Indonesia adalah bangsa yang ber-Tuhan dan menolak faham anti Tuhan (atheisme). Bangsa Indonesia wajib menyembah Tuhan dan beribadah sesuai agama dan kepercayaan masing-

13 Asri Budiningsih, Pembelajaran Moral: Berpijak Pada Karakteristik Siswa dan Budayanya (Jakarta: Rineka Cipta, 2004), hal. 8 
masing secara leluasa. Berkeadaban dan berkeadilan. Masyarakat Indonesia melaksanakan perintah agama dengan tetap mengedepankan harmoni dalam kehidupan bermasyarakat, berbangsa dan bernegara dan pada dasarnya masyarakat Indonesia menjalankan perintah agama dan kepercayaan masing-masing dengan cara berbudi pekerti luhur dan saling menghormati.

Nilai (2) Sila Kemanusiaan Yang Adil Dan Beradab: menegaskan bahwa Indonesia adalah negara bangsa (nation state), bersatu dan berdaulat menuju kepada kekeluargaan bangsa-bangsa di dunia. Bangsa Indonesia adalah bangsa yang menghendaki pergaulan bangsa-bangsa di dunia dengan prinsip saling menghormati nilai-nilai nasionalisme setiap bangsa yang tumbuh subur dalam tamansari pergaulan bangsa-bangsa dunia. Pada prinsipnya menegaskan bahwa bangsa indonesia merupakan bagian dari kemanusiaan universal yang menjunjung tinggi HAM dan mengembangkan persaudaraan dunia berdasarkan nilai-nilai keadilan dan keadaban.

Nilai (3) Sila Persatuan Indonesia: pada prinsipnya, berdirinya negara Indonesia adalah untuk seluruh rakyat Indonesia, bukan negara untuk satu kelompok maupun untuk satu golongan. Persatuan Indonesia bernafaskan semangat kebangsaan yang melindungi segenap bangsa dan seluruh tumpah darah Indonesia yang senasip sepenanggungan dalam bingkai Negara Kesatuan Republik Indonesia. Persatuan Indonesia adalah sikap kebangsaan yang saling menghormati perbedaan dan keberagaman masyarakat dan bangsa Indonesia. Persatuan Indonesia menegaskan bahwa Indonesia bukanlah bangsa yang sempit, melaikan bangsa yang menghormati eksistensi bangsa lain.

Nilai (4) Sila Kerakyatan Yang Dipimpin Oleh Hikmat Kebijaksanaan Dalam Permusyawaratan dan Perwakilan: 
menegaskan bahwa negara Indonesia adalah negara demokrasi yang mengakui dan menjunjung tinggi kedaulatan rakyat. Bangsa Indonesia memelihara dan mengembangkan semangat bermusyawarah untuk mufakat dalam pengambilan setiap keputusan. Rakyat Indonesia meyakini bahwa dengan jalan musyawarah untuk mufakat dapat menjaga keselamatan dan keberlangsungan bangsa dan negara. Bangsa Indonesia sangat tidak mengenal sistem diktator mayoritas dan tirani minoritas. Dalam mengambil keputusan senantiasa dipimpin oleh nilai-nilai ketuhanan, kemanusiaan, persatuan dan keadilan dalam semangat hikmat kebijaksanaan dalam permusyawaratan untuk mewujudkan keadilan.

Nilai yang terakhir (5) Adalah Sila Keadilan Sosial Bagi Seluruh Rakyat Indonesia: Negara Indonesia didirikan untuk bersungguh-sungguh memajukan kesejahteraan bagi seluruh rakyat Indonesia baik lahir maupun bathin. Setiap warga negara berhak untuk mendapatkan pekerjaan dan penghidupan yang layak, bermartabat, dan berkeadilan bagi kemanusiaan. Negara Indonesia wajib menjamin setiap warga negara untuk mendapatkan pendidikan, pekerjaan dan penghidupan yang layak, bermartabat dan berkeadilan. ${ }^{14}$

Gambaran pembentukan moral manusia Indonesia seutuhnya dalam nilai-nilai pancasila dapat diilustrasikan dalam kelima butir pancasila. Pada sila pertama tersirat bagaimana manusia Indonesia berhubungan dengan Tuhannya atau kepercayaannya. Dapat ditelaah dari sila pertama yang berbunyi "Ketuhanan Yang Maha Esa", menganut suatu kepercayaan 50\% memengaruhi penganutnya berperilaku baik. Karena setiap agama pasti mengajarkan nilai-nilai kebaikan bagi umat yang menganut

${ }^{14}$ Bahan Tayang Materi Sosialisasi Empat Pilar MPR RI ( Jakarta: Sekretariat Jendral MPR RI, 2016) hal 20-23 
dan mempercayai ajarannya dengan baik. Nilai-nilai seperti memanusiakan manusia, mengamalkan cinta kasih pada sesama dan lingkungan sekitar, dan toleransi terhadap sesama umat manusia.

Pada sila kedua tergambar bagaimana manusia Indonesia harus bersikap hidup dengan orang lain sebagaimana layaknya manusia yang punya pikiran dan ahklak hingga dia bisa bersikap sebagai mahkluk yang tertinggi dibandingkan dengan mahkluk lainnya yaitu binatang. Sila ketiga menerangkan bagaimana bangas Indonesia menciptakan suatu pandangan betapa pentingnya arti persatuan dan kesatuan bangsa dari pada bercerai berai seperti pada pepatah bersatu kita teguh dan bercerai kita runtuh. Sila keempat menegaskan bagaimana bangsa Indonesia mengimplementasikan cara bersikap dan berpendapat serta memutuskan sesuatu masalah yang menyangkut kepentingan umum secara bijak demi kelangsungan kehidupan berdemokrasi.

Dalam sila kelima dijabarkan bagaimana bangsa Indonesia mewujudkan suatu keadilan dan kemakmuran bagi seluruh masyarakat Indonesia itu sendiri. Dari penjabaran kelima sila tersebut di atas, maka sudah sepantasnya bahwa Pancasila beserta kelima silanya itu layak dijadikan sebagai pandangan dan pegangan hidup serta dijadikan sebagai pembimbing dalam menciptakan kerangka berpikir untuk menjalankan roda demokratisasi dan diimplementasikan dalam segala macam praktik kehidupan menyangkut berbangsa, bernegara dan bermasyarakat di dalam Negara kesatuan Republik Indonesia.

\section{F. Penutup}

Pancasila sebagai sebuah dasar dan ideologi bangsa memiliki makna yang sangat dalam. Dalam setiap butir-butir 
pancasila memiliki nilai-nilai yang harus dijadikan sebagai dasar dan pandangan dalam menapaki kehidupan dan bermasyarakat di tanah Indonesia. Pancasila dengan nilainilai luhur yang terkandung di dalamnya menjadi basis utama dari pendidikan moral dan pendidikan karakter dalam mengarungi keberagaman bangsa Indonesia. Dalam setiap butir-butir pancasila adalah dasar pendidikan moral. Perkembangan zaman semakin pesat, bangsa Indonesia pun dituntut untuk mengikuti perkembangan. Modernisasi tidak bisa dihindari, akan tetapi moral bangsa Indonesia harus tetap dipegang erat. Keberagaman, pendidikan moral, pendidikan karakter, budaya bangsa harus senantiasa difahami dan dihayati. Perubahan dan modernisasi harus diikuti dengan peningkatan kualitas moral dengan nilai-nilai luhur pancasila.

\section{Referensi}

Budiningsih, Asri, Pembelajaran Moral: Berpijak Pada Karakteristik Siswa Dan Budayanya (Jakarta: Rineka Cipta, 2004)

Hamidi, Jazim dan Luthfi, Mustafa, Civic Education Antara Realitas Politik dan Implementasi Hukumnya (Jakarta: PT Gramedia Pustaka Utama, 2010)

Haricahyono, Cheppy, Dimensi-Dimensi Pendidikan Moral (Semarang: IKIP Semarang Press, 1995)

Kansil dan Christin, Modul Pancasila dan Kewarganegaraan (Jakatra: PT Pradnya Paramita, 2005)

Kusumohamidjojo, Kebhinekaan Masyarakat Indonesia: Suatu Problematik Filsafat Kebudayaan, (Jakarta: Grasindo, 2000)

Likumahua, Sastra Suatu Sarana Pendidikan Informal, (Salatiga: Widya Sari Press Salatiga, 2001) 
Mahfud, Pendidikan Multikultural (Yogyakarta: Pustaka Pelajar, 2005)

Tobroni, dkk, Pendidikan Kewarganegaraan, Demokrasi, HAM, Civic Society dan Multikulturalisme (Malang: Posapom, 2007) 